\title{
RETROUTERINE PERFORATED GANGRENOUS APPENDICITIS
}

\author{
Dubravko Habek ${ }^{1,2}$, Marko Sever ${ }^{3}$ and Jasna Čerkez Habek ${ }^{4}$ \\ ${ }^{1}$ Department of Obstetrics and Gynecology, Sveti Duh University Hospital, Zagreb, Croatia; \\ ${ }^{2}$ Croatian Catholic University, Zagreb, Croatia; \\ ${ }^{3}$ Department of Surgery, Sveti Duh University Hospital, Zagreb, Croatia; \\ ${ }^{4}$ Department of Internal Medicine, Sveti Duh University Hospital and Croatian Catholic University, \\ Zagreb, Croatia
}

\begin{abstract}
SUMMARY - We present an atypical case of retrouterine gangrenous perforated appendicitis with Douglas abscess in a 33-year-old woman, with clinical picture developing over two weeks. Laparotomy and appendectomy with abdominal drainage and antibiosis were performed and resulted in complete recovery.
\end{abstract}

Key words: Appendicitis; Abdomen, acute; Abscess; Laparotomy; Appendectomy; Case reports

\section{Introduction}

Basic anatomic variations of the appendix position may be pelvic and retrocecal, but may also vary from preileal, subileal, postileal to subcecal position. Thus, the position of the appendix will be in direct correlation with normal or abnormal clinical presentation of appendicitis or acute abdomen, and has a potential impact on the resulting complications such as peritonitis and serious intra-abdominal infections ${ }^{1,2}$.

In the literature, retrouterine appendix position is not described as a separate entity and the reason for appendectomy, so this paper presents an atypical case of retrouterine gangrenous perforated appendicitis with Douglas abscess and clinical picture of acute abdomen.

\section{Case Report}

A 33-year-old woman was admitted to the emergency gynecologic service with signs of acute abdo-

Correspondence to: Prof. Dubravko Habek, $M D, P h D$, Department of Obstetrics and Gynecology, Sveti Duh University Hospital, Sveti Duh 64, HR-10000 Zagreb, Croatia

E-mail: dhabek@unicath.hr

Received January 28, 2016, accepted January 23, 2018 men. In the past two weeks, she had occasional hypogastric pain without nausea, vomiting, difficulty in defecation or frequent urination. She was febrile for the last three days with temperature up to $39^{\circ} \mathrm{C}$, chills and shivering. The patient took antipyretics and was on a diet prescribed by her family doctor, with no signs of acute abdomen and normal laboratory findings. Gynecologic history was uneventful, without genital infections, pregnancy or delivery, with regular menstrual cycle, and Papanicolaou cytodiagnostic swabs were normal. Her personal and family history was without significant pathology. At admission, she was conscious, eupneic and febrile $\left(38.7^{\circ} \mathrm{C}\right)$. Gynecologic examination showed normal uterine and adnexa clinical finding, and existence of a smooth, painful tumor mass in the Douglas area that caused bulging of the posterior fornix. The abdomen was painful to defense musculaire in the hypogastric area, more pronounced supraumbilically, almost without peristalsis. Surgical examination ruled out the typical picture of acute appendicitis based on local history and clinical findings. Transvaginal ultrasound examination showed normal uterine and ovarian morphometry, with the entire Douglas space filled by a heteroechogenic mass of $10 \mathrm{~cm}$ in greatest diameter, without detectable blood flow. Multi-slice computed tomography showed low locat- 


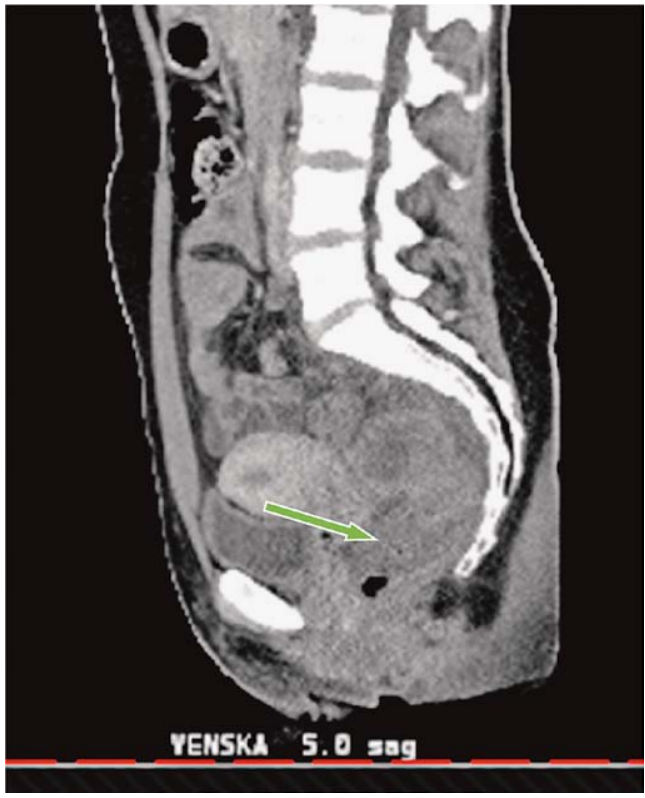

Fig. 1. Multi-slice computed tomography: Douglas abscess due to retrouterine perforated gangrenous appendicitis.

ed cecum, undetectable appendix with edematous convolutions, ileum and Douglas area filled by oval $5 \times 5 \times 6$ $\mathrm{cm}$ mass with dense liquid and free gas, thickened wall with mesenteric fat reaction, rectum compression to the left and to the sacrum, and enlarged regional nodes (Fig. 1). Laboratory findings: C-reactive protein 213 $\mathrm{mg} / \mathrm{L}$; leukocytes $14.23 \times 10^{9}$; normal urinogram. Because of acute abdomen and Douglas abscess of unknown etiology, possibly perforated pyosalpinx, Pfannenstiel laparotomy was performed and purulent peritonitis with adhesive obliteration of Douglas space with sigmoid colon was found. Adhesiolysis was performed and $100 \mathrm{~mL}$ of green pus was found with retrouterine location of fixed perforated gangrenous appendix, $14 \mathrm{~cm}$ in length. The appendix was mobilized and appendectomy with necrectomy of gangrenous appendix tissue (fixed to the bottom of Douglas area) was performed. Internal genital organs were morphologically normal, catarrhally changed. Abdominal cavity was washed with warm saline. A drain was inserted into Douglas area. The wound incision was closed. Therapy with clindamycin, gentamicin and metronidazole with crystalloid infusion was prescribed. Escherichia coli was isolated in the purulent exudate. The postoperative period was complicated by wound infection from which Fusobacterium mortiferum and Bacteroides ovatus were isolated. The infection was resolved with antibiosis (amoxicillin) and regular wound toilette and bandage. On postoperative day 13, the patient was discharged from the hospital in good general condition and normal vital functions. Histopathologic findings pointed to gangrenous appendicitis.

\section{Discussion}

As mentioned above, appendix topography in the pelvis or retrocecally will dictate development of clinical symptoms of appendicitis and possible atypical clinical finding. Vascular obstruction caused by inflammation of appendicular artery can cause ischemia, gangrene and subsequent appendix perforation, which can last for up to several days, especially if it is located retrocecally. It is believed that the risk of gangrenous appendicitis perforation is significantly higher in retrocecal position, reported to be $22 \%-67 \%{ }^{2}$. In the conditions of the appendix pelvic position, which is significantly less frequently encountered (20\%-22\%), the appendix hangs freely on the mesentery and may secondarily cause catarrhal inflammation of the right adnexa (salpingoophoritis) and focal peritonitis, especially if it is elongated. Other very rarely described appendix position is subhepatic, usually conditioned by innate bowel malrotation or appendix repression by pregnant uterus ${ }^{2-4}$. Retrouterine pelvic appendix position is not described in any case in the literature. Les$\operatorname{lie}^{5}$ reports on the possibility of retrouterine appendix position in pregnancy, interpreting possible cecum malposition caused by gravid uterus and consequent severe clinical course of the disease with complicated surgical procedure but without real case studies. The typical clinical picture of acute appendicitis (peritonitis, periumbilical pain, nausea, vomiting) was absent in our patient due to atypical pelvic retrouterine appendix position with the tip of the long appendix in Douglas area. Atypical inappetence for a few days without febrile illness and passage disorders, and good general state of the patient did not indicate additional diagnostic workup. Only high temperature of up to 39 ${ }^{\circ} \mathrm{C}$ indicated development of infection, however, even then with no signs of acute abdomen, which would correspond to phlegmonous-gangrenous inflammation stage of the appendix to the final perforation and Douglas abscess formation. Development of appendicitis of atypical position and duration evidently lasted for a long time, eventually resulting in gangrenous per- 
forated appendicitis with Douglas abscess, peritonitis and acute abdominal pain, which was diagnosed on admission and operatively relieved with good patient's recovery.

\section{References}

1. Dominguez EP, Sweeney JF, Choi YU. Diagnosis and management of diverticulitis and appendicitis. Gastroenterol Clin North Am. 2006;35:367-91.
2. Mwachaka P, El-busaidy H, Sinkeet S, Ogeng'o J. Variations in the position and length of the vermiform appendix in a black Kenyan population. ISRN Anat. 2014:871048. doi: 10.1155/ 2014/871048.

3. Herscu G, Kong A, Russell D. Retrocecal appendix location and perforation at presentation. Am Surg. 2006;72:890-3.

4. Clegg-Lamptey JN, Armah H, Naaeder SB, Adu-Aryee NA. Position and susceptibility to inflammation of vermiform appendix in Accra, Ghana. East Afr Med J. 2006;83:670-3.

5. Leslie D. Surgical emergencies in pregnancy. Aust N Z J Obstet Gynecol. 1966;6:200.

Sažetak

\title{
RETROUTERINI PERFORIRANI GANGRENOZNI APENDICITIS
}

\author{
D. Habek, M. Sever i J. Čerkez Habek
}

Prikazan je atipičan slučaj retrouterino smještenog gangrenoznog perforiranog apendicitisa s Douglasovim apscesom u 33-godišnje žene koja je tijekom dva tjedna razvijala atipičnu kliničku sliku. Učinjena je laparotomija, apendektomija i abdominalna drenaža s antibiozom i potpunim oporavkom bolesnice.

Ključne riječi: Apendicitis; Abdomen, akutni; Apsces; Laparotomija; Apendektomija; Prikazi slučaja 